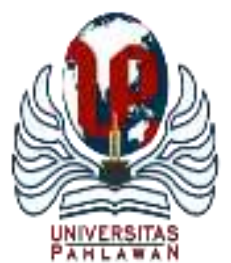

Edukatif : Jurnal Ilmu Pendidikan Volume 3 Nomor 6 Tahun 2021 Halm 4541 - 4555

EDUKATIF: JURNAL ILMU PENDIDIKAN

Research \& Learning in Education

https:/ledukatif.org/index.php/edukatif/index

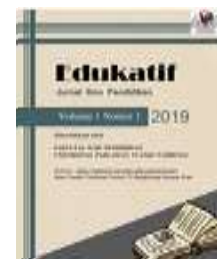

\title{
Managing MSME Innovation Performance: Analysis of Knowledge-Oriented Leadership and Knowledge Management Capability
}

\author{
Suroso $^{1 凶}$, Dewiana Novitasari $^{2}$, Yunianto Agung Nugroho ${ }^{3}$, Gusli Chidir $^{4}$, Masduki Asbari ${ }^{5}$ \\ STMIK Insan Pembangunan, Indonesia ${ }^{1,3,4,5}$ \\ Sekolah Tinggi Ilmu Ekonomi Insan Pembangunan, Indonesia ${ }^{2}$ \\ E-mail : suroso.ip@gmail.com ${ }^{1}$, dhewiediosa@ yahoo.co.id ${ }^{2}$, yunianto.nugroho76@ gmail.com ${ }^{3}$, \\ gchd.ch@gmail.com ${ }^{4}$, kangmasduki.ssi@gmail.com ${ }^{5}$
}

\begin{abstract}
Abstrak
Tujuan penelitian ini adalah menyelidiki praktik dan efek knowledge-oriented leadership terhadap terhadap kinerja inovasi di industri UMKM, dengan mediasi kapabilitas manajemen pengetahuan. Pendekatan Partial Least Square (PLS) digunakan untuk menganalisis data yang diperoleh dari 170 karyawan beberapa UMKM di Banten. Hasil yang diperoleh menunjukkan bahwa knowledge-oriented leadership memberi pengaruh yang positif dan signifikan terhadap kapabilitas manajemen pengetahuan, tetapi tidak berpengaruh signifikan terhadap kinerja inovasi organisasi. Walaupun demikian, knowledge-oriented leadership berpengaruh positif dan signifikan terhadap kinerja inovasi organisasi melalui kapabilitas manajemen pengetahuan. Jadi kapabilitas manajemen pengetahuan berfungsi sebagai variabel mediator penuh. Dari perspektif teoritis, hasil penelitian ini memberikan bukti empiris tentang peran positif kapabilitas manajemen pengetahuan sebagai faktor yang berpengaruh untuk meningkatkan kinerja inovasi UMKM. Sedangkan, dari perspektif manajerial, hasil penelitian ini memberikan gambaran pengambil keputusan di UMKM dengan pemahaman yang lebih baik tentang bagaimana meningkatkan kapabilitas manajemen pengetahuan dan menerapkan gaya kepemimpinan yang sesuai di era pengetahuan saat ini.
\end{abstract}

Kata kunci: Kinerja inovasi, kapabilitas manajemen pengetahuan, knowledge-oriented leadership.

\begin{abstract}
The purpose of this study was to investigate the practice and effect of knowledge-oriented leadership on innovation performance in the MSME industry, by mediating knowledge management capabilities. The Partial Least Square (PLS) approach was used to analyze the data obtained from 170 employees of several MSMEs in Banten. The results obtained indicate that knowledge-oriented leadership has a positive and significant effect on knowledge management capabilities, but has no significant effect on organizational innovation performance. However, knowledge-oriented leadership has a positive and significant impact on organizational innovation performance through knowledge management capabilities. So knowledge management capability functions as a full mediator variable. From a theoretical perspective, the results of this study provide empirical evidence about the positive role of knowledge management capability as an influential factor to improve MSME innovation performance. Meanwhile, from a managerial perspective, the results of this study provide an overview of decision-makers in MSMEs with a better understanding of how to improve knowledge management capabilities and apply appropriate leadership styles in the current knowledge era.
\end{abstract}

Keywords: Innovation performance, knowledge management capability, knowledge-oriented leadership.

Copyright (c) 2021 Suroso, Dewiana Novitasari, Yunianto Agung Nugroho, Gusli Chidir, Masduki Asbari

$\triangle$ Corresponding author

Email : suroso.ip@gmail.com

DOI : https://doi.org/10.31004/edukatif.v3i6.1506 
4542 Managing MSME Innovation Performance: Analysis of Knowledge-Oriented Leadership and Knowledge Management Capability - Suroso, Dewiana Novitasari, Yunianto Agung Nugroho, Gusli Chidir, Masduki Asbari

DOI: https://doi.org/10.31004/edukatif.v3i6.1506

\section{INTRODUCTION}

Innovation is a crucial factor for a company to maintain its competitive advantage and become a market leader. In a knowledge-based society, business organizations face not only the challenge of offering innovative products and services through effective exploitation of the knowledge resources available to (Asbari, 2020; Asbari, Santoso, et al., 2020b; Novitasari, Goestjahjanti, et al., 2020; Novitasari, Yuwono, et al., 2020; Sudiyono et al., 2020), but also challenges how they capture it and use the available knowledge beyond their limits (Asbari, Purba, et al., 2021a). The knowledge-based view of the enterprise considers knowledge as a strategic resource that organizations can create value by exploring and exploiting through proper management and gaining a competitive market position. Proper knowledge management requires leaders to influence their companies for the acquisition and constructive application of knowledge (Asbari \& Novitasari, 2020a). Due to the shift of leadership from the industrial era to the knowledge era, knowledgeoriented leadership has become a core factor in organizations to meet challenges in innovation (Novitasari, Asbari, et al., 2020; Sutardi et al., 2020; Zaman et al., 2020). Nevertheless, maintaining an organization's competitive advantage is becoming an increasingly difficult management task in this era of the Industrial Revolution 4.0, due to several factors such as rapid technological developments, changes in customer preferences and needs, as well as increasing competition. As a result, organizations seeking to adopt and adapt several strategies (e.g., knowledge management, and innovation) have proven effectiveness in achieving high levels of performance (Asbari, Purba, et al., 2021a; Asbari \& Novitasari, 2020b; Kamar et al., 2020; Novitasari, Asbari, et al., 2021; Novitasari \& Asbari, 2020; Singgih et al., 2020). Among these strategies, innovation is considered by several studies to be the main source of organizational competitive advantage (Asbari, Chi Hyun, et al., 2020a; Asbari, Fayzhall, et al., 2020; Asbari, Hyun, et al., 2020b; Asbari \& Novitasari, 2020a, 2021; Fayzhall et al., 2020; Goestjahjanti et al., 2020; Novitasari, Yuwono, et al., 2020; Suprapti et al., 2020). Furthermore, the ability to take advantage of innovation is the main engine and driver of economic growth (Agistiawati et al., 2020; Hutagalung et al., 2020). Menurut Asbari, Prasetya, et al. (2021); Asbari, Wijayanti, et al. (2020), the modern economy is being and continues to be built by ideas that are translated into creative outputs. Therefore, improving innovation performance becomes an unavoidable choice for organizations in today's highly competitive environment.

Lack of knowledge as a factor inhibiting innovation is the concern of this study because it is an obstacle to the innovation performance of MSMEs in Indonesia. These obstacles take various forms such as the lack of qualified human resources (HR), lack of information about technology, lack of information about the market, and difficulties in finding collaborative partners for innovation (Fikri et al., 2020; Novitasari, Kumoro, et al., 2020; Nugroho et al., 2021; Putra et al., 2020, 2021). Thus, the important role of knowledge management requires research that investigates "how" and "how big" the role of knowledge management in enhancing innovation. Nonetheless, proper knowledge management requires leaders to influence their companies for the acquisition and constructive application of knowledge, due to the shift in leadership from the industrial era to the knowledge era (Asbari, 2020; Asbari, Santoso, et al., 2020a; Hutagalung, Asbari, et al., 2020; Jumiran et al., 2020; Maesaroh et al., 2020; Nuryanti et al., 2020), knowledge-oriented leadership is a core factor in organizations to meet challenges in open innovation. For this, organizational management requires knowledge management capabilities to enhance open innovation.

Although research interest in leadership and knowledge management capabilities is growing, limited empirical research is directed at the direct effect of knowledge management-oriented leadership and innovation (direct effect). Donate and de Pablo (2015) were among the pioneers in contributing to leadership theory and knowledge management by presenting a model, which explains how knowledge-oriented leadership promotes effective knowledge management. However, the study aims to explain the indirect role of 
4543 Managing MSME Innovation Performance: Analysis of Knowledge-Oriented Leadership and Knowledge Management Capability - Suroso, Dewiana Novitasari, Yunianto Agung Nugroho, Gusli Chidir, Masduki Asbari

DOI: https://doi.org/10.31004/edukatif.v3i6.1506

leadership, namely by exploring the relationship between knowledge-oriented leadership and innovation through knowledge management practices. However, the study ignores how knowledge-oriented leadership can directly affect innovation performance, so there is a research gap in explaining the direct relationship between knowledge-oriented leadership and innovation performance. Empirically, research on the influence of knowledge management capabilities on innovation performance is also not massive, if any, the variables used are knowledge management variables in general (Hung et al., 2010). Therefore, re-examining the effect of knowledge management capabilities on innovation performance will provide a solid foundation that helps decision-makers to answer this critical question: how can our company be innovative?

The problems and gaps in the literature mentioned above motivated this study to investigate the effect of knowledge-oriented leadership on innovation performance by using knowledge management capability as a mediator. The purpose of this study, which is expected to reduce uncertainty about this relationship. Therefore, the main research questions in this study are:

Q1: Does knowledge-oriented leadership affect knowledge management capability?

Q2: Does knowledge management capability affect innovation performance?

Q3: Does knowledge management capability act as a mediator on the relationship between knowledge- oriented leadership and innovation performance?

By answering this question, it is hoped that this research can contribute to both academics and practitioners, as they will reduce the gaps in the relevant literature that have been identified above (Ooi, 2009). Furthermore, the results of the study will help MSME managers to overcome one of the main inhibiting factors for innovation performance, represented by a lack of knowledge. To do so, knowledge management practices have been identified based on several previous studies. Knowledge management capability has been recognized through three processes as proposed by Lin \& Lee (2005), namely knowledge acquisition, knowledge application, and knowledge sharing. This research is organized as follows: starting with a discussion of the relationship between variables, and then the research hypothesis is introduced. The next section describes the research methods, data analysis, and results, while the last section presents conclusions, study limitations, and recommendations for further research.

\section{RESEARCH METHOD}

According to Creswell \& Creswell (2017), if the purpose of this study is to determine the relationship between the variables studied, the quantitative approach is the best. Quantitative research methods are suitable for testing theories and hypotheses through the use of a set of statistical tools (Creswell \& Creswell, 2017). Therefore, this study uses a survey method to test the formulated hypothesis, and a questionnaire was adopted as an instrument to collect the required data. The research population consisted of 170 employees of several MSMEs in the City of a Thousand Industries, Tangerang. As suggested and adopted by previous research, the appropriate respondents of this study are the managers in the company, from team heads to top managers, because they hold critical positions in the organization that enable them to be able to provide reliable information about the basic environment and characteristics of their organization (Hung et al., 2010). Using simple random sampling, 200 questionnaires were sent online to the population. 170 questionnaires were returned and valid, which makes up a response rate of 85\%. Roscoe's (1975) rule of thumb suggests that the sample size is more than 30 and less than 500 is appropriate for most studies, therefore, the obtained sample size for this study is considered appropriate.

Due to the nature of this study involving a dependent effect between latent constructs and manifest variables, the reflective measurement model is suitable for this study (Hair Jr et al., 2017). All adopted items were rated on a five-point Likert scale from 1 (strongly disagree) to 5 (strongly agree). Knowledge-oriented 
4544 Managing MSME Innovation Performance: Analysis of Knowledge-Oriented Leadership and Knowledge Management Capability - Suroso, Dewiana Novitasari, Yunianto Agung Nugroho, Gusli Chidir, Masduki Asbari

DOI: https://doi.org/10.31004/edukatif.v3i6.1506

leadership is measured using six items (KL1-KL6) from Donate \& de Pablo (2015). Innovation performance was measured using seven items (KI1-KI7) from Cavusgil et al. (2003) and Prajogo \& Hong (2008), and have been validated by (Yusr et al., 2017). Meanwhile, to measure knowledge management capabilities in organizations, thirteen items were adapted from Lin \& Lee (2005). The thirteen items are distributed into three dimensions as proposed by Lin \& Lee (2005), namely the dimensions of knowledge acquisition as many as 4 items (AKU1-AKU4), dimensions of knowledge application as many as 5 items (APL1-APL5), and dimensions of knowledge sharing as many as 4 items (BP1-BP4). Preliminary research on 30 respondents was conducted to ensure the reliability and validity of the above measurements in the context of MSME employees in Indonesia. The results of the pilot study show that there are several invalid items (namely: AKU2, APL1, and APL3) that need to be removed from the model. While the new model can be seen in Figure 2.

The most popular statistical techniques under the Structural Equation Model SEM are the covariancebased approach (CB-SEM) and the variance-based partial least squares technique (PLS-SEM) (Sarstedt et al., 2014). However, PLS-SEM has recently received wide attention in many disciplines such as marketing, strategic management, management information systems, and other disciplines (Hair et al., 2012). The ability of PLS-SEM to deal with problematic modeling problems that are common in the social science environment such as unusual data characteristics (e.g., non-normal data) and highly complex models is an important reason behind the increased use of this approach. Considering the advantages of this approach, this study uses PLS SEM to fully test the proposed hypothesis. SmartPLS software is performed to evaluate each outer model and inner model. Testing of the outer model is carried out to ensure the reliability and validity of the measurements, while the hypotheses introduced are checked through the inner model.

Table 1. Research Items List

\begin{tabular}{llll}
\hline Notations & \multicolumn{1}{c}{ Item } & References \\
\hline Knowledge-oriented Leadership (KL) & $\begin{array}{l}\text { Donate \& de Pablo } \\
(2015)\end{array}$ & \\
\hline KL1 & $\begin{array}{l}\text { Leadership has created an environment that supports } \\
\text { responsible employee behavior and teamwork. }\end{array}$ & & \\
\hline KL2 & $\begin{array}{l}\text { Managers are accustomed to taking on the role of knowledge } \\
\text { leaders, especially characterized by openness, tolerance for } \\
\text { faults, and mediation for the achievement of company goals. }\end{array}$ & \\
\hline KL3 & $\begin{array}{l}\text { Managers encourage learning from experience, tolerating } \\
\text { mistakes up to a point. }\end{array}$ & \\
\hline KL4 & $\begin{array}{l}\text { Managers behave as advisors, and control is solely on the } \\
\text { assessment of goal attainment. }\end{array}$ & \\
\hline KL5 & Managers promote the acquisition of external knowledge. \\
\hline KL6 & $\begin{array}{l}\text { Managers reward employees who share and apply their } \\
\text { knowledge. }\end{array}$ \\
\hline
\end{tabular}

\begin{tabular}{lll}
\hline $\begin{array}{l}\text { Knowledge Management (KM) Capability } \\
\text { Knowledge Acquisition: }\end{array}$ & Lin \& Lee (2005) \\
\hline AQ1 & Our company has a process for acquiring supplier knowledge. \\
\hline AQ2 & $\begin{array}{l}\text { Our company has a process for generating new knowledge } \\
\text { based on existing knowledge. }\end{array}$ & \\
\hline AQ3 & Our company has a process to acquire customer knowledge. \\
\hline AQ4 & $\begin{array}{l}\text { Our company has a process for acquiring knowledge about } \\
\text { developing new products/services. }\end{array}$ \\
\hline
\end{tabular}


4545 Managing MSME Innovation Performance: Analysis of Knowledge-Oriented Leadership and Knowledge Management Capability - Suroso, Dewiana Novitasari, Yunianto Agung Nugroho, Gusli Chidir, Masduki Asbari

DOI: https://doi.org/10.31004/edukatif.v3i6.1506

\begin{tabular}{lll}
\hline Notations & \multicolumn{1}{c}{ Item } & References \\
\hline & \\
\hline Knowledge Application: & $\begin{array}{l}\text { Our company has processes for integrating different sources } \\
\text { and types of knowledge. }\end{array}$ \\
\hline AP1 & $\begin{array}{l}\text { Our company has a process for transferring organizational } \\
\text { knowledge to employees. }\end{array}$ \\
\hline AP2 & Our company has a process to filter knowledge. \\
\hline AP3 & $\begin{array}{l}\text { Our company has a process for applying experience-based } \\
\text { knowledge. }\end{array}$ \\
\hline AP4 & $\begin{array}{l}\text { Our company has a process of applying knowledge to solve } \\
\text { new problems. }\end{array}$ \\
\hline AP5
\end{tabular}

\begin{tabular}{|c|c|c|}
\hline \multicolumn{3}{|c|}{ Knowledge Sharing: } \\
\hline SH1 & $\begin{array}{l}\text { Our company has a process for distributing knowledge } \\
\text { throughout the organization. }\end{array}$ & \\
\hline SH2 & $\begin{array}{l}\text { Our company has a process for distributing knowledge among } \\
\text { our business partners. }\end{array}$ & \\
\hline SH3 & $\begin{array}{l}\text { Our company has a standard reward system for sharing } \\
\text { knowledge. }\end{array}$ & \\
\hline SH4 & $\begin{array}{l}\text { Our company designs processes to facilitate knowledge sharing } \\
\text { across functional boundaries. }\end{array}$ & \\
\hline \multicolumn{2}{|c|}{ Innovation Performance (IP) } & \multirow{3}{*}{$\begin{array}{l}\text { Cavusgil et al. (2003) } \\
\text { dan Prajogo \& Hong } \\
(2008)\end{array}$} \\
\hline KI1 & $\begin{array}{l}\text { The number of introductions of our new products is quite high } \\
\text { compared to other competitors }\end{array}$ & \\
\hline KI2 & $\begin{array}{l}\text { Compared to other competitors, our company is faster in } \\
\text { bringing new products to market }\end{array}$ & \\
\hline $\mathrm{KI} 3$ & $\begin{array}{l}\text { Our company encourages new ideas that are presented to } \\
\text { improve performance }\end{array}$ & \\
\hline KI4 & $\begin{array}{l}\text { Our new product introductions have increased over the past } 5 \\
\text { years }\end{array}$ & \\
\hline KI5 & $\begin{array}{l}\text { Our company changes the production method at high speed } \\
\text { compared to other competitors }\end{array}$ & \\
\hline KI6 & Our company's technological competitiveness is high & \\
\hline KI7 & $\begin{array}{l}\text { Over the past five years, our company has developed many new } \\
\text { management approaches }\end{array}$ & \\
\hline
\end{tabular}

In line with the above discussion, this study proposes the following main hypothesis: Knowledge management capability has a significant effect on innovation performance. Therefore, the following hypothesis are developed:

H1: Knowledge-oriented leadership has a significant effect on knowledge management capability.

H2: Knowledge-oriented leadership has a significant effect on innovation performance.

H3: Knowledge management capability has a significant effect on innovation performance.

H4: Knowledge-oriented leadership has a significant effect on innovation performance through knowledge management capabilities. 
4546 Managing MSME Innovation Performance: Analysis of Knowledge-Oriented Leadership and Knowledge Management Capability - Suroso, Dewiana Novitasari, Yunianto Agung Nugroho, Gusli Chidir, Masduki Asbari

DOI: https://doi.org/10.31004/edukatif.v3i6.1506

Based on the previous discussion, a theoretical framework is introduced as shown in Figure 1 below:

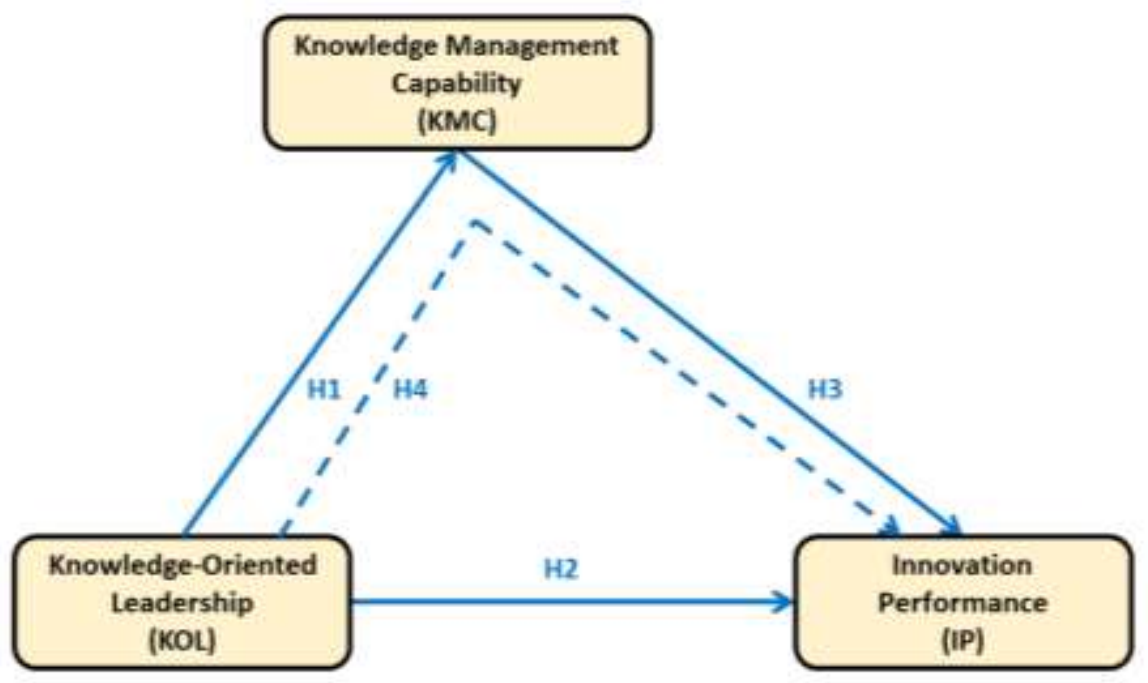

Figure 1. Research Conceptual Model

\section{RESULT AND DISCUSSION}

\section{Result}

A total of 170 MSME employees participated. Most were men (69\%), then women (31\%). They have different age groups, under 30 years (25\%), ranging from 30-40 years (47\%), and over 40 years (28\%). Their tenure as employees also varied, some of them were under 5 years (36\%), ranging from 5-10 years (48\%), and more than 10 years (16\%). The majority of education is diploma/bachelor $(94 \%)$ then high School (6\%).

Table 2. Sample Description

\begin{tabular}{|c|c|c|c|}
\hline \multicolumn{2}{|c|}{ Criteria } & \multirow{2}{*}{\begin{tabular}{|c|} 
Total \\
117 \\
\end{tabular}} & \multirow{2}{*}{$\begin{array}{c}\% \\
69 \%\end{array}$} \\
\hline Age & Men & & \\
\hline & Women & 53 & $31 \%$ \\
\hline \multirow[t]{3}{*}{ Age (per March 2021) } & $<30$ years old & 43 & $25 \%$ \\
\hline & $30-40$ years old & 79 & $47 \%$ \\
\hline & $>40$ years old & 48 & $28 \%$ \\
\hline \multirow[t]{3}{*}{ Years of Service } & $<5$ years & 61 & $36 \%$ \\
\hline & $5-10$ years & 82 & $48 \%$ \\
\hline & $>10$ years & 27 & $16 \%$ \\
\hline \multirow[t]{2}{*}{ Highest Education } & Diploma/Bachelo & 160 & $94 \%$ \\
\hline & High School & 10 & $6 \%$ \\
\hline
\end{tabular}

The measurement model testing phase includes testing of convergent validity, discriminant validity. Meanwhile, to test construct reliability, Cronbach's alpha and composite reliability were used. The results of the PLS analysis can be used to test research hypotheses if all indicators in the PLS model have met the 
4547 Managing MSME Innovation Performance: Analysis of Knowledge-Oriented Leadership and Knowledge Management Capability - Suroso, Dewiana Novitasari, Yunianto Agung Nugroho, Gusli Chidir, Masduki Asbari

DOI: https://doi.org/10.31004/edukatif.v3i6.1506

requirements of convergent validity, discriminant validity, and reliability testing. Convergent validity test is done by looking at the loading factor value of each indicator to the construct. In most references, a factor weight of 0.5 or more is considered to have strong enough validation to explain latent constructs (Chin, 1998; Ghozali, 2014; Hair et al., 2010). In this study, the minimum accepted loading factor is 0.7 and provided that the AVE value of each construct is $>0.5$ (Ghozali, 2014). After going through SmartPLS 3.0 processing, all indicators or research items have a loading factor value above 0.7 and an AVE value above 0.5 . The fit or valid model of this study can be seen in Figure 2. Thus, the convergent validity of this research model has met the requirements. The value of loadings, Cronbach's alpha, composite reliability, and AVE for each construct can be seen in Figure 2 and Table 3.

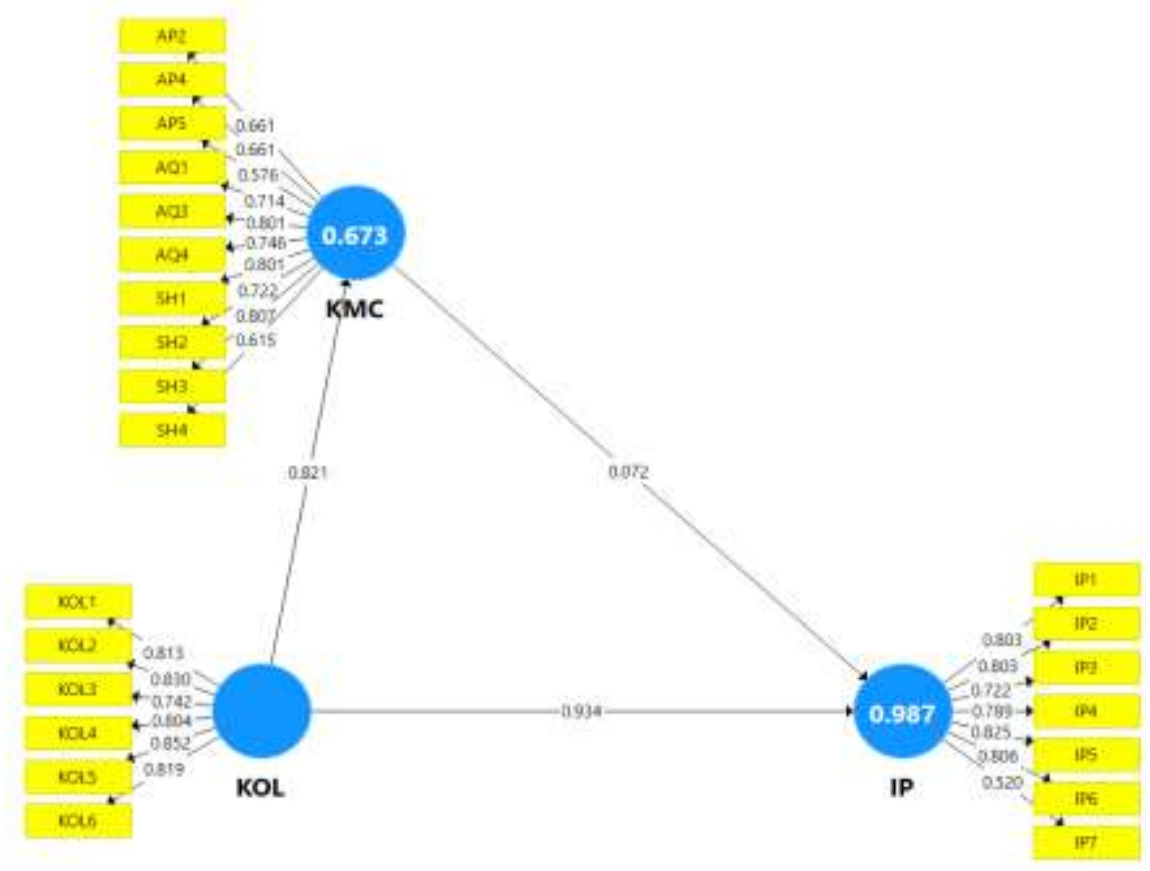

Figure 2. Valid Research Model

Table 3. Items Loadings, Cronbach's Alpha, Composite Reliability, and Average Variance Extracted (AVE)

\begin{tabular}{|c|c|c|c|c|c|c|}
\hline Variables & Items & Loadings & $\begin{array}{l}\text { Cronbach's } \\
\text { Alpha }\end{array}$ & rho_A & $\begin{array}{l}\text { Composite } \\
\text { Reliability }\end{array}$ & AVE \\
\hline \multirow[t]{6}{*}{$\begin{array}{l}\text { Knowledge-oriented Leadership } \\
\text { (KOL) }\end{array}$} & KOL1 & 0,813 & 0,895 & 0,898 & 0,920 & 0,657 \\
\hline & KOL2 & 0,830 & & & & \\
\hline & KOL3 & 0,742 & & & & \\
\hline & KOL4 & 0,804 & & & & \\
\hline & KOL5 & 0,852 & & & & \\
\hline & KOL6 & 0,819 & & & & \\
\hline \multirow{7}{*}{$\begin{array}{l}\text { Knowledge Management (KM) } \\
\text { Capability }\end{array}$} & AP2 & 0,661 & 0,893 & 0,905 & 0,912 & 0,511 \\
\hline & AP4 & 0,661 & & & & \\
\hline & AP5 & 0,576 & & & & \\
\hline & AQ1 & 0,714 & & & & \\
\hline & AQ3 & 0,801 & & & & \\
\hline & AQ4 & 0,746 & & & & \\
\hline & SH1 & 0,801 & & & & \\
\hline
\end{tabular}


4548 Managing MSME Innovation Performance: Analysis of Knowledge-Oriented Leadership and Knowledge Management Capability - Suroso, Dewiana Novitasari, Yunianto Agung Nugroho, Gusli Chidir, Masduki Asbari

DOI: https://doi.org/10.31004/edukatif.v3i6.1506

\begin{tabular}{|c|c|c|c|c|c|c|}
\hline & SH2 & 0,722 & & & & \\
\hline & SH3 & 0,807 & & & & \\
\hline & SH4 & 0,615 & & & & \\
\hline \multirow[t]{7}{*}{ Innovation Performance (IP) } & IP1 & 0,803 & 0,874 & 0,888 & 0,903 & 0,576 \\
\hline & IP2 & 0,803 & & & & \\
\hline & IP3 & 0,722 & & & & \\
\hline & IP4 & 0,789 & & & & \\
\hline & IP5 & 0,825 & & & & \\
\hline & IP6 & 0,806 & & & & \\
\hline & IP7 & 0,520 & & & & \\
\hline
\end{tabular}

Table 4. Discriminant Validity

\begin{tabular}{llll}
\hline Variables & IP & KMC & KOL \\
\hline & & & \\
\hline IP & 0,759 & & \\
\hline KMC & 0,838 & 0,715 & \\
\hline KOL & 0,993 & 0,821 & 0,811 \\
\hline
\end{tabular}

Table 5. Collinearity Statistics (VIF)

\begin{tabular}{llll}
\hline Variables & IP & KMC & KOL \\
\hline IP & & & \\
\hline KMC & 3,060 & & \\
\hline KOL & 3,060 & 1,000 & \\
\hline
\end{tabular}

Discriminant validity is carried out to ensure that each concept of each latent variable is different from other latent variables. The model has good discriminant validity if the AVE squared value of each exogenous construct (the value on the diagonal) exceeds the correlation between the construct and other constructs (the value below the diagonal) (Ghozali, 2014). The results of the discriminant validity test are using the AVE squared value, namely by looking at the Fornell-Larcker Criterion Value obtained as shown in Table 4. The discriminant validity test results in table 3 above show that all constructs have an AVE square root value above the correlation value with other latent constructs (via the Fornell-Larcker criterion). Likewise, the crossloading value of all items from one indicator is greater than the other indicator items as mentioned in Table 4, so it can be concluded that the model has met discriminant validity (Fornell \& Larcker, 1981). Furthermore, a collinearity evaluation was carried out to find out whether there was collinearity in the model. To find collinearity, it is necessary to calculate the VIF of each construct. If the VIF score is higher than 5, then the model has collinearity (Hair et al., 2014). As shown in Table 5, all VIF scores are less than 5, meaning that this model does not have collinearity problems.

Construct reliability can be assessed from the value of Cronbach's alpha and composite reliability of each construct. The recommended value of composite reliability and Cronbach's alpha is more than 0.7 (Ghozali, 2014). The results of the reliability test in table 2 above show that all constructs have composite reliability and Cronbach's alpha values greater than 0.7 (>0.7). In conclusion, all constructs have met the required reliability.

Hypothesis testing in PLS is also known as inner model testing. This test includes a test of the significance of direct and indirect effects as well as measuring the magnitude of the effect of exogenous variables on endogenous variables. To determine the effect of knowledge-oriented leadership on innovation performance through knowledge management capabilities as a mediating variable, a direct and indirect 
4549 Managing MSME Innovation Performance: Analysis of Knowledge-Oriented Leadership and Knowledge Management Capability - Suroso, Dewiana Novitasari, Yunianto Agung Nugroho, Gusli Chidir, Masduki Asbari

DOI: https://doi.org/10.31004/edukatif.v3i6.1506

influence test is needed. The effect test was carried out using the t-statistical test in the partial least squared (PLS) analysis model using the SmartPLS 3.0 software. With the bootstrapping technique, the R Square value and the significance test value were obtained as Table 6 and Table 7 below:

Table 6. R Square Value

\begin{tabular}{lcc}
\hline & R Square & R Square Adjusted \\
\hline IP & & \\
\hline KMC & 0,987 & 0,987 \\
\hline & 0,673 & 0,671 \\
\hline
\end{tabular}

Table 7. Hypotheses Testing

\begin{tabular}{llcllccl}
\hline Hypotheses & Relationship & $\begin{array}{l}\text { Original } \\
\text { Sample } \\
(\mathrm{O})\end{array}$ & $\begin{array}{l}\text { Sample } \\
\text { Mean } \\
(\mathrm{M})\end{array}$ & $\begin{array}{l}\text { Standard } \\
\text { Deviation } \\
(\mathrm{STDEV})\end{array}$ & $\begin{array}{l}\text { T Statistics } \\
(|\mathrm{O} / \mathrm{STDEV}|\end{array}$ & $\begin{array}{l}\text { P } \\
\text { Values }\end{array}$ & Decision \\
\hline H1 & KOL -> KMC & 0,821 & 0,824 & 0,023 & 35,959 & 0,000 & $\begin{array}{l}\text { Supporte } \\
\mathrm{d}\end{array}$ \\
\hline H2 & KOL -> IP & 0,934 & 0,939 & 0,022 & 42,349 & 0,000 & $\begin{array}{l}\text { Supporte } \\
\mathrm{d}\end{array}$ \\
\hline H3 & KMC -> IP & 0,072 & 0,066 & 0,025 & 2,817 & 0,005 & $\begin{array}{l}\text { Supporte } \\
\mathrm{d}\end{array}$ \\
\hline H4 & KOL -> KMC -> & 0,059 & 0,055 & 0,021 & 2,776 & 0,006 & $\begin{array}{l}\text { Supporte } \\
\mathrm{d}\end{array}$ \\
\hline
\end{tabular}

Based on Table 6 above, the R Square value of knowledge management capability (KM) is 0.709 , which means that the knowledge management capability (KM) variable can be explained by the knowledgeoriented leadership (KL) variable of $70.9 \%$, while the remaining $29.1 \%$ is explained by the variable knowledge-oriented leadership (KL) not discussed in this study. While the R Square value of innovation performance (KI) is 0.673 which means that the innovation performance variable (KI) can be explained by knowledge-oriented leadership (KL) and the knowledge management capability (KM) variable is 67.3\%, while the remaining $32.7 \%$ is explained by the other variables not discussed in this study. Meanwhile, Table 7 displays the t-statistics and p-values that show the influence between the research variables that have been mentioned.

\section{Discussion}

Based on a comprehensive review of the relevant literature, this study proposes a structural model of the relationship between some different domains in the current MSME industry, namely knowledge-oriented leadership, knowledge management capabilities, and innovation performance. In essence, this study was successful in investigating and clarifying the role of knowledge-oriented leadership and mediating knowledge management capabilities in enhancing innovation performance. The perception of MSME employees in Tangerang Indonesia as a source of information has successfully tested the hypotheses and models used in the study. The results of this study provide empirical evidence that knowledge-oriented leadership has a positive and significant effect on knowledge management capability (H1 is proven/supported). Interestingly, this study also finds the fact that knowledge-oriented leadership has a significant effect on organizational innovation performance (H2 is proven/supported). From a theoretical perspective, the results of this study 
4550 Managing MSME Innovation Performance: Analysis of Knowledge-Oriented Leadership and Knowledge Management Capability - Suroso, Dewiana Novitasari, Yunianto Agung Nugroho, Gusli Chidir, Masduki Asbari

DOI: https://doi.org/10.31004/edukatif.v3i6.1506

strengthen empirical evidence about the positive role of knowledge-oriented leadership style on knowledge management. This finding is generally in line with the findings in previous studies conducted by Asbari, Purba, et al. (2021c), (2021b); Asbari \& Prasetya (2021); John et al. (2021); Novitasari, Haque, et al. (2021); Novitasari, Supriatna, et al. (2021); Novitasari \& Asbari (2021). While the unique finding of this study regarding the absence of leadership influence on innovation performance, is different from the findings of previous research conducted by Novitasari, Kumoro, et al. (2020); Purwanto, Bernardo, Asbari, Wijayanti, et al. (2020); Putra et al. (2021); Suprapti et al. (2020); Waruwu et al. (2020).

This study also finds evidence that knowledge management capability has a significant positive effect on innovation performance (H3 is proven/supported). These results are supported by Darroch (2005) who considers knowledge management as a necessary process to achieve the desired innovation performance. Further analysis carried out by this study determined that the three knowledge management capabilities (ie, knowledge acquisition, knowledge application, and knowledge sharing) were mediators of the relationship between the influence of knowledge-oriented leadership on innovation performance (H4 proven/supported). This conclusion, in line with Hung et al. (2010) argues that the main output of knowledge management capabilities is knowledge and that this output is not the final target, but rather, as a tool to achieve the desired goal of improving the overall performance of the company. Therefore, providing this knowledge to the right person, at the right time, so that he/she makes the right decision is the main reason behind the important role of knowledge management in improving performance.

On the other hand, from a managerial perspective, the results of this study provide an overview of decision-makers in MSMEs with a better understanding of how leadership and workplace practices are and how to improve knowledge management capabilities. Based on these logical and plausible findings, managers should focus on establishing a system in which the acquired knowledge can be accessed and applied by different departments to improve innovation performance. The process of acquiring knowledge is one of the antecedents needed to improve innovation performance. Therefore, attention should be paid to building and enhancing the organization's ability to acquire knowledge and update it continuously.

Undoubtedly, the present study has several limitations that need to be highlighted. First, this study has only examined the direct and indirect relationships between the investigated variables (ie, knowledge-oriented leadership, knowledge management capabilities, and innovation performance). Therefore, it is recommended to extend this research by investigating the interaction relationship between other relevant variables, such as the relationship of the influence of the knowledge-oriented leadership variable on financial performance, knowledge infrastructure, personal motivation, and so on. It is also suggested to examine the moderating or mediating role of other related variables, such as organizational citizenship behavior to provide further insight into this issue. It is also advisable to investigate the relationship between knowledge management capabilities and different aspects of innovation rather than testing innovation performance in general, which would help broaden our understanding of this relationship.

Given that this study focuses on the relationship model between knowledge-oriented leadership, knowledge management capability, and innovation performance, for future research, the authors recommend accommodating more predictors and comparing their explanatory abilities with those assessed in this study. Future research could also try to correct the shortcomings of this study by including more control variables (e.g., member differences in gender, generational variance $\mathrm{X}, \mathrm{Y}, \mathrm{Z}$, and so on), or by surveying more team members across different industries and cultures. 
4551 Managing MSME Innovation Performance: Analysis of Knowledge-Oriented Leadership and Knowledge Management Capability - Suroso, Dewiana Novitasari, Yunianto Agung Nugroho, Gusli Chidir, Masduki Asbari

DOI: https://doi.org/10.31004/edukatif.v3i6.1506

\section{CONCLUSION}

Innovation performance has proven to be one of the important indicators to achieve organizational success, which is sustainable. In this regard, acquiring and managing knowledge has been recognized as one of the important requirements for strengthening performance innovation. Therefore, the main objective of this study is to find out empirically about the effect of knowledge-oriented leadership on innovation performance in the MSME industry, either directly or indirectly through the mediation of knowledge management capabilities, in the perspective of employees. The findings of this study emphasize that the organization's ability to practice knowledge-oriented leadership is very influential in acquiring knowledge and utilizing it. Therefore, our findings recommend effective knowledge-oriented leadership practices to improve and accelerate knowledge management capabilities. Likewise, recommending the implementation of a good knowledge management process to improve the company's innovation performance. This conclusion has significant consequences for MSME management policies in Indonesia.

\section{REFERENCES}

Agistiawati, E., Asbari, M., Basuki, S., Yuwono, T., \& Chidir, G. (2020). Exploring The Impact Of Knowledge Sharing And Organizational Culture On Teacher Innovation Capability. International Journal Of Science And Management Studies (IJSMS), 3(3), 62-77.

Asbari, M. (2020). Is Transformational Leadership Suitable For Future Organizational Needs? International Journal Of Sociology, Policy And Law (Ijospl), 01(01), 51-55. Https://Ijospl.Org/Index.Php/Ijospl/Article/View/17

Asbari, M., Chi Hyun, C., Wijayanti, L. M., Imelda, D., \& Purwanto, A. (2020). Hard Skills Atau Soft Skills: Manakah Yang Lebih Penting Bagi Inovasi Guru. Edumaspul - Jurnal Pendidikan, 4(1), 1-20. Https://Www.Researchgate.Net/Publication/339274657_Hard_Skills_Atau_Soft_Skills_Manakah_Yang _Lebih_Penting_Bagi_Inovasi_Guru

Asbari, M., Fayzhall, M., Goestjahjanti, F. S., Winanti, Yuwono, T., Hutagalung, D., Basuki, S., Maesaroh, S., Mustofa, Chidir, G., Yani, A., \& Purwanto, A. (2020). Peran Kepemimpinan Transformasional Dan Organisasi Pembelajaran Terhadap Kapasitas Inovasi Sekolah. Edupsycouns: Journal Of Education, Psychology And Counseling, 2(1), 6724-6748. Https://Ummaspul.EJournal.Id/Edupsycouns/Article/View/421

Asbari, M., Hyun, C. C., Wijayanti, L. M., Winanti, Fayzhall, M., \& Putra, F. (2020). Hard Skills Dan Soft Skills: Apa Membangun Inovasi Guru Sekolah Islam? Journal EVALUASI, 4(1), 143. Https://Doi.Org/10.32478/Evaluasi.V4i1.362

Asbari, M., \& Novitasari, D. (2020a). Pengaruh Aktivitas Berbagi Pengetahuan Dan Mediasi Budaya Terhadap Kemampuan Inovasi Guru. Jurnal Manajemen Dan Supervisi Pendidikan, 5(1), 324-334. Http://Journal2.Um.Ac.Id/Index.Php/Jmsp/Article/View/15253

Asbari, M., \& Novitasari, D. (2020b). Pengaruh Kesiapan Untuk Berubah Di Masa Pandemi Covid-19: Apa Yang Dibutuhkan Pemimpin Untuk Menjaga Kinerja. Jurnal Ekonomika: Manajemen, Akuntansi, Dan Perbankan Syari'ah, 9(2), 1-17. Https://Doi.Org/Https://Doi.Org/10.24903/Je.V9i2.932

Asbari, M., \& Novitasari, D. (2021). Pengaruh Aktivitas Berbagi Pengetahuan Dan Mediasi Budaya Terhadap Kemampuan Inovasi Guru. JMSP (Jurnal Manajemen Dan Supervisi Pendidikan), 5(1), 324-334.

Asbari, M., \& Prasetya, A. B. (2021). Managerial Coaching: Rahasia Membangun Kinerja, Komitmen Tim Dan Modal Psikologis Guru. Edumaspul - Jurnal Pendidikan, 5(1), 490-506. Https://Ummaspul.EJournal.Id/Maspuljr/Article/View/1248

Asbari, M., Prasetya, A. B., Santoso, P. B., \& Purwanto, A. (2021). From Creativity To Innovation: The Role 
4552 Managing MSME Innovation Performance: Analysis of Knowledge-Oriented Leadership and Knowledge Management Capability - Suroso, Dewiana Novitasari, Yunianto Agung Nugroho, Gusli Chidir, Masduki Asbari

DOI: https://doi.org/10.31004/edukatif.v3i6.1506

Of Female Employees' Psychological Capital. International Journal Of Social And Management Studies (IJOSMAS), 02(02), 66-77. Https://Ijosmas.Org/Index.Php/Ijosmas/Article/View/18

Asbari, M., Purba, J. T., Hariandja, E. S., \& Sudibjo, N. (2021a). From Leadership To Innovation: Managing Employee Creativity. Jurnal Manajemen Strategi Dan Aplikasi Bisnis, 4(1), 143-154.

Asbari, M., Purba, J. T., Hariandja, E. S., \& Sudibjo, N. (2021b). From Leadership To Innovation: Managing Employee Creativity. Jurnal Manajemen Strategi Dan Aplikasi Bisnis, 4(1), 143-154. Https://Doi.Org/Https://Doi.Org/10.36407/Jmsab.V4i1.287

Asbari, M., Purba, J. T., Hariandja, E. S., \& Sudibjo, N. (2021c). Membangun Kesiapan Berubah Dan Kinerja Karyawan: Kepemimpinan Transformasional Versus Transaksional. Jurnal Ilmiah Manajemen Dan Bisnis, 22(1), 54-71.

Asbari, M., Santoso, P. B., \& Prasetya, A. B. (2020a). Elitical And Antidemocratic Transformational Leadership Critics: Is It Still Relevant? (A Literature Study). International Journal Of Sociology, Policy And Law (Ijospl), 01(01), 11-16. Https://Doi.Org/Https://Doi.Org/10.8888/Ijospl.V1i1.10

Asbari, M., Santoso, P. B., \& Prasetya, A. B. (2020b). Elitical And Antidemocratic Transformational Leadership Critics: Is It Still Relevant? (A Literature Study). International Journal Of Social, Policy And Law, 1(1), 12-16.

Asbari, M., Wijayanti, L., Hyun, C. C., Purwanto, A., \& Santoso, P. B. (2020). How To Build Innovation Capability In The RAC Industry To Face Industrial Revolution 4.0? International Journal Of Psychosocial Rehabilitation, 24(6), 2008-2027. Https://Doi.Org/10.37200/IJPR/V24I6/PR260192

Cavusgil, S. T., Calantone, R. J., \& Zhao, Y. (2003). Tacit Knowledge Transfer And Firm Innovation Capability. Journal Of Business \& Industrial Marketing.

Chin, W. (1998). The Partial Least Squares Approach To Structural Equation Modeling (E. Modern Methods For Business Research, In: G. A. Marcoulides (Ed.)). Lawrence Erlbaum Associates Publisher.

Creswell, J. W., \& Creswell, J. D. (2017). Research Design: Qualitative, Quantitative, And Mixed Methods Approaches. Sage Publications.

Darroch, J. (2005). Knowledge Management, Innovation And Firm Performance. Journal Of Knowledge Management.

Donate, M. J., \& De Pablo, J. D. S. (2015). The Role Of Knowledge-Oriented Leadership In Knowledge Management Practices And Innovation. Journal Of Business Research, 68(2), 360-370.

Fayzhall, M., Asbari, M., Purwanto, A., Basuki, S., Hutagalung, D., Maesaroh, S., Chidir, G., Goestjahjanti, F. S., \& Andriyani, Y. (2020). Pengaruh Gaya Kepemimpinan Terhadap Kapabilitas Inovasi Guru Dalam Perspektif Organizational Learning. Edupsycouns: Journal Of Education, Psychology And Counseling, 2(1), 64-91. Https://Ummaspul.E-Journal.Id/Edupsycouns/Article/View/413

Fikri, M. A. A., Asbari, M., Purwanto, A., Nugroho, Y. A., Waruwu, H., Fauji, A., Shobihi, A. W., Singgih, E., Sudiyono, R. N., Agistiawati, E., \& Dewi, W. R. (2020). A Mediation Role Of Organizational Learning On Relationship Of Hard Skills, Soft Skills, Innovation And Performance: Evidence At Islamic School. Edupsycouns: Journal Of Education, Psychology And Counseling, 2(1), 398-423. Https://Ummaspul.E-Journal.Id/Edupsycouns/Article/View/498

Fornell, C., \& Larcker, D. F. (1981). Evaluating Structural Equation Models With Unobservable Variables And Measurement Error. Journal Of Marketing Research, 18(1), 39. Https://Doi.Org/10.2307/3151312

Ghozali, I. (2014). Structural Equation Modeling, Metode Alternatif Dengan Partial Least Square (PLS) (4th Ed.). Badan Penerbit Universitas Diponegoro.

Goestjahjanti, F. S., Asbari, M., Purwanto, A., Agistiawati, E., Fayzhall, M., Radita, F. R., Maesaroh, S., Asnaini, S. W., Chidir, G., Yani, A., Singgih, E., Sudiyono, R. N., Basuki, S., Yuwono, T., Hutagalung, D., Wijayanti, L. M., \& Hyun, C. C. (2020). Pengaruh Organizational Learning Terhadap Peningkatan 
4553 Managing MSME Innovation Performance: Analysis of Knowledge-Oriented Leadership and Knowledge Management Capability - Suroso, Dewiana Novitasari, Yunianto Agung Nugroho, Gusli Chidir, Masduki Asbari

DOI: https://doi.org/10.31004/edukatif.v3i6.1506

Hard Skills, Soft Skills Dan Inovasi Guru. Edupsycouns: Journal Of Education, Psychology And Counseling, 2(1), 87-97. Https://Ummaspul.E-Journal.Id/Edupsycouns/Article/View/436

Hair, J. F., Black, W. C., Babin, B. J., \& Anderson, R. E. (2010). Multivariate Data Analysis (7th Ed.). Pearson Prentice Hall.

Hair, J. F., Hult, G. T., Ringle, C. M., \& Sarstedt, M. (2014). A Primer Partial Least Squaresstructural Equation Modeling (PLS-SEM). SAGE Publications.

Hair, Joe F, Sarstedt, M., Ringle, C. M., \& Mena, J. A. (2012). An Assessment Of The Use Of Partial Least Squares Structural Equation Modeling In Marketing Research. Journal Of The Academy Of Marketing Science, 40(3), 414-433.

Hair Jr, J. F., Sarstedt, M., Ringle, C. M., \& Gudergan, S. P. (2017). Advanced Issues In Partial Least Squares Structural Equation Modeling. Sage Publications.

Hung, R. Y.-Y., Lien, B. Y.-H., Fang, S.-C., \& Mclean, G. N. (2010). Knowledge As A Facilitator For Enhancing Innovation Performance Through Total Quality Management. Total Quality Management, $21(4), 425-438$.

Hutagalung, D., Asbari, M., Fayzhall, M., Ariyanto, E., Agistiawati, E., Sudiyono, R. N., Waruwu, H., Goestjahjanti, F. S., Winanti, \& Yuwono, T. (2020). Peran Religiusitas, Kepemimpinan Transformasional, Kepuasan Kerja Dan Mediasi Organizational Citizenship Behavior Terhadap Kinerja Guru. Edupsycouns: Journal Of Education, Psychology And Counseling, 2(1), 311-326. Https://Ummaspul.E-Journal.Id/Edupsycouns/Article/View/483

Hutagalung, D., Sopa, A., Asbari, M., Cahyono, Y., Maesaroh, S., \& Chidir, G. (2020). Influence Of Soft Skills, Hard Skills And Organization Learning On Teachers' Performance Through Innovation Capability As Mediator. Journal Of Critical Reviews, 7(19), 54-66.

Johan, M., Budiadnyana, G. N., Admiral, Asbari, M., \& Novitasari, D. (2021). Kepemimpinan Karismatik Dalam Perspektif Karyawan UMKM: Dari Motivasi Intrinsik Hingga Tacit Knowledge Sharing. Edumaspul: Jurnal Pendidikan, 5(1), 598-613. Https://Ummaspul.EJournal.Id/Maspuljr/Article/View/1303

Jumiran, Novitasari, D., Nugroho, Y. A., Sutardi, D., Sasono, I., \& Asbari, M. (2020). Pengaruh Dimensi Kepemimpinan Transformasional Terhadap Kepuasan Kerja Dan Komitmen Organisasional: Studi Kasus Pada Dosen Perguruan Tinggi Swasta. Edupsycouns: Journal Of Education, Psychology And Counseling, 2(1), 600-621. Https://Ummaspul.E-Journal.Id/Edupsycouns/Article/View/555

Kamar, K., Novitasari, D., Asbari, M., Winanti, W., \& Goestjahjanti, F. S. (2020). Enhancing Employee Performance During The Covid-19 Pandemic: The Role Of Readiness For Change Mentality. JDM (Jurnal Dinamika Manajemen), 11(2), 154-166.

Lin, H. F., \& Lee, G. G. (2005). Impact Of Organizational Learning And Knowledge Management Factors On E-Business Adoption. Management Decision, 43(2), 171-188. Https://Doi.Org/10.1108/00251740510581902

Maesaroh, S., Asbari, M., Hutagalung, D., Agistiawati, E., Basuki, S., Radita, F. R., Nurasiah, Yulia, Y., Singgih, E., \& Chidir, G. (2020). Pengaruh Religiusitas Dan Kepemimpinan Transformasional Terhadap Kinerja Guru Melalui Mediasi Organizational Citizenship Behavior. Edupsycouns: Journal Of Education, Psychology And Counseling, 2(1), 276-290. Https://Ummaspul.EJournal.Id/Edupsycouns/Article/View/473

Novitasari, D., \& Asbari, M. (2020). Pengaruh Kepemimpinan Transformasional Terhadap Kinerja Karyawan: Peran Kesiapan Untuk Berubah Sebagai Mediator. Jurnal Manajemen, 10(2), 84-99. Https://EJurnal.Lppmunsera.Org/Index.Php/JM/Article/View/2371

Novitasari, D., \& Asbari, M. (2021). Leaders Coaching Di Sekolah: Apa Perannya Terhadap Kinerja Guru? Edumaspul: Jurnal Pendidikan, 5(1), 580-597. Https://Ummaspul.E- 
4554 Managing MSME Innovation Performance: Analysis of Knowledge-Oriented Leadership and Knowledge Management Capability - Suroso, Dewiana Novitasari, Yunianto Agung Nugroho, Gusli Chidir, Masduki Asbari

DOI: https://doi.org/10.31004/edukatif.v3i6.1506

Journal.Id/Maspuljr/Article/View/1299

Novitasari, D., Asbari, M., \& Sasono, I. (2021). Analisis Pengaruh Religiusitas Dan Kualitas Pelayanan Terhadap Kepuasan Kerja: Studi Kasus Pada Karyawan Industri Manufaktur. Jurnal Manajemen Strategi Dan Aplikasi Bisnis, 4(1), 117-130.

Novitasari, D., Asbari, M., Wijayanti, L. M., Hyun, C. C., \& Farhan, M. (2020). The Role Of Religiosity, Leadership Style, Job Satisfaction And Organizational Citizenship Behavior Mediation On Woman Teachers' Performance. Solid State Technology, 63(6), 2953-2967. Http://Solidstatetechnology.Us/Index.Php/JSST/Article/View/3380

Novitasari, D., Goestjahjanti, F. S., \& Asbari, M. (2020). The Role Of Readiness To Change Between Transformational Leadership And Performance: Evidence From A Hospital During Covid-19 Pandemic. APMBA (Asia Pacific Management And Business Application), 9(1), 37-56.

Novitasari, D., Haque, M. G., Supriatna, H., Asbari, M., \& Purwanto, A. (2021). Understanding The Links Between Charismatic Leadership, Intrinsic Motivation And Tacit Knowledge Sharing Among MSME Employees. International Journal Of Social And Management Studies (IJOSMAS), 02(03), 1-13. Https://Www.Ijosmas.Org/Index.Php/Ijosmas/Article/View/29

Novitasari, D., Kumoro, D. F. C., Yuwono, T., \& Asbari, M. (2020). Authentic Leadership And Innovation: What Is The Role Of Psychological Capital? International Journal Of Science And Management Studies (IJSMS), 3(5), 27-42. Https://Www.Ijsmsjournal.Org/Volume3-Issue5.Html

Novitasari, D., Supriatna, H., Asbari, M., Nugroho, Y. A., \& Nadeak, M. (2021). Exploring The Impact Of Trust In Leader And Knowledge Sharing On Employee Innovation. International Journal Of Social And $\begin{array}{llll}\text { Management } \quad \text { Studies } & \text { (IJOSMAS), } & \text { 02(03), }\end{array}$ Https://Www.Ijosmas.Org/Index.Php/Ijosmas/Article/View/30

Novitasari, D., Yuwono, T., Cahyono, Y., Asbari, M., Sajudin, M., Radita, F. R., \& Asnaini, S. W. (2020). Effect Of Hard Skills, Soft Skills, Organizational Learning And Innovation Capability On Indonesian Teachers’ Performance During Covid-19 Pandemic. Solid State Technology, 63(6), 2927-2952.

Nugroho, Y. A., Putra, F., Novitasari, D., Asbari, M., \& Purwanto, A. (2021). Developing Innovation Capability: Between Individual And Organizational Factors. International Journal Of Social And $\begin{array}{llll}\text { Management } & \text { Studies } & \text { (IJOSMAS), } & \text { 01(01), }\end{array}$ Https://Doi.Org/Https://Doi.Org/10.5555/Ijosmas.V1i1.9

Nuryanti, Y., Novitasari, D., Nugroho, Y. A., Fauji, A., Gazali, \& Asbari, M. (2020). Meningkatkan Komitmen Organisasional Dosen: Analisis Pengaruh Kepemimpinan Perguruan Tinggi Dan Kepuasan Intrinsik \& Ekstrinsik Dosen. Edupsycouns: Journal Of Education, Psychology And Counseling, 2(1), 561-581. Https://Ummaspul.E-Journal.Id/Edupsycouns/Article/View/551

Ooi, K.-B. (2009). TQM And Knowledge Management: Literature Review And Proposed Framework. African Journal Of Business Management, 3(11), 633-643.

Prajogo, D. I., \& Hong, S. W. (2008). The Effect Of TQM On Performance In R\&D Environments: A Perspective From South Korean Firms. Technovation, 28(12), 855-863.

Purwanto, A., Bernarto, I., Asbari, M., Wijayanti, L. M., Choi, \&, \& Hyun, C. (2020). The Impacts Of Leadership And Culture On Work Performance In Service Company And Innovative Work Behavior As Mediating Effects. Journal Of Reseacrh In Business, Economics, And Education, 2(1), 283-291. Http://E-Journal.Stie-Kusumanegara.Ac.Id

Putra, A. S., Novitasari, D., Asbari, M., Purwanto, A., Iskandar, J., Hutagalung, D., \& Cahyono, Y. (2020). Examine Relationship Of Soft Skills, Hard Skills, Innovation And Performance: The Mediation Effect Of Organizational Learning. International Journal Of Science And Management Studies (IJSMS), 3(3), 27-43. Http://Www.Ijsmsjournal.Org/2020/Volume-3 Issue-3/Ijsms-V3i3p104.Pdf

Putra, A. S., Waruwu, H., Asbari, M., Novitasari, D., \& Purwanto, A. (2021). Leadership In The Innovation 
4555 Managing MSME Innovation Performance: Analysis of Knowledge-Oriented Leadership and Knowledge Management Capability - Suroso, Dewiana Novitasari, Yunianto Agung Nugroho, Gusli Chidir, Masduki Asbari

DOI: https://doi.org/10.31004/edukatif.v3i6.1506

Era: Transactional Or Transformational Style? International Journal Of Social And Management Studies (IJOSMAS), 01(01), 89-96. Https://Doi.Org/Https://Doi.Org/10.5555/Ijosmas.V1i1.10

Sarstedt, M., Ringle, C. M., Smith, D., Reams, R., \& Hair Jr, J. F. (2014). Partial Least Squares Structural Equation Modeling (PLS-SEM): A Useful Tool For Family Business Researchers. Journal Of Family Business Strategy, 5(1), 105-115.

Singgih, E., Iskandar, J., Goestjahjanti, F. S., Fahlevi, M., Nadeak, M., Fahmi, K., Anwar, R., Asbari, M., \& Purwanto, A. (2020). The Role Of Job Satisfaction In The Relationship Between Transformational Leadership, Knowledge Management, Work Environment And Performance. Solid State Technology, 63(2s), 293-314. Http://Www.Solidstatetechnology.Us/Index.Php/JSST/Article/View/1556

Sudiyono, R. N., Goestjahjanti, F. S., Asbari, M., Fayzhall, M., Yani, A., Winanti, Yuwono, T., Nurasiah, Yulia, Y., Singgih, E., \& Chidir, G. (2020). Meningkatkan Komitmen Dan Kinerja Dosen : Apa Peran Manajemen Perguruan Tinggi ? Edupsycouns: Journal Of Education, Psychology And Counseling, 2(1), 337-352. Https://Ummaspul.E-Journal.Id/Edupsycouns/Article/View/489/283

Suprapti, Asbari, M., Cahyono, Y., \& Mufid, A. (2020). Leadership Style, Organizational Culture And Innovative Behavior On Public Health Center Performance During Pandemic Covid-19. Journal Of Industrial Engineering \& Management Research, $1(2)$. Https://Doi.Org/Https://Doi.Org/10.7777/Jiemar.V1i2

Sutardi, D., Novitasari, D., Asbari, M., Silitonga, N., Nugroho, Y. A., Hutagalung, D., Mustofa, Chidir, G., Basuki, S., \& Yuwono, T. (2020). Pengaruh Work-Family Conflict, Stres Kerja Dan Social Support Terhadap Kepuasan Kerja: Studi Kasus Pada Guru Wanita Di Tangerang. Edupsycouns: Journal Of Education, Psychology And Counseling, 2(1), 482-498. Https://Ummaspul.EJournal.Id/Edupsycouns/Article/View/513

Waruwu, H., Asbari, M., Purwanto, A., Nugroho, Y. A., Fikri, M. A. A., Fauji, A., Shobihi, A. W. I., Hulu, P., Sudiyono, R. N., Agistiawati, E., \& Dewi, W. R. (2020). The Role Of Transformational Leadership, Organizational Learning And Structure On Innovation Capacity: Evidence From Indonesian Private Schools. Edupsycouns: Journal Of Education, Psychology And Counseling, 2(1), 378-397. Https://Ummaspul.E-Journal.Id/Edupsycouns/Article/View/499

Yusr, M. M., Mokhtar, S. S. M., Othman, A. R., \& Sulaiman, Y. (2017). Does Interaction Between TQM Practices And Knowledge Management Processes Enhance The Innovation Performance? International Journal Of Quality \& Reliability Management.

Zaman, M. N., Novitasari, D., Goestjahjanti, F. S., Fahlevi, M., Nadeak, M., Fahmi, K., Setiawan, T., \& Asbari, M. (2020). Effect Of Readiness To Change And Effectiveness Of Transformational Leadership On Workers ' Performance During Covid-19 Pandemic. Solid State Technology, 63(1s), 185-200. Http://Www.Solidstatetechnology.Us/Index.Php/JSST/Article/View/708 